\title{
Biofunctional nanomaterials based on ultrafine silica, protein and aminocarbohydrates
}

\author{
N. P. Galagan, N. Y. Klymenko, I. L. Orel, E. A. Novikova, V. V. Turov \\ O. O. Chuiko Institute of Surface Chemistry, NAS of Ukraine \\ 17 Generala Naumova Str., 03164, Kyiv, Ukraine \\ nklymenko@ukr.net
}

\begin{abstract}
Aim. Investigation of adsorptive interactions of $N$-acetyl-D-glucosamine (GlcNAc) and $N$-acetylneuraminic acid (NANA) with ultra fine silica (UFS) modified by protein bovine serum albumin (BSA). Methods. Adsorption, IR-, ${ }^{I} H$ NMR- and laser Doppler spectroscopy. Results. Conditions for obtaining bionanocomposites (BNC) UFS/GlcNAc, UFS/BSA/GlcNAc and UFS/BSA/NANA are developed. Conclusions. Impellent ability of deconservated bovine gametes decreased in the presence of BNC after adsorptive fastening of protein on UFS surface. The ${ }^{l} H$ NMR spectroscopy data proved that interaction of GlcNAc with protein was accompanied by essential dehydratation of protein molecules.
\end{abstract}

Keywords: ultra fine silica, albumin, carbohydrates, bionanocomposites, bovine sperm.

Introduction. Ultrafine silica (UFS) is a promising carrier for immobilization of many synthetic and natural compounds which allows creating biologically active nanocomposites (BNC) for biotechnologies on its basis $[1,2]$. Large specific surface area of UFS $\left(S_{s p}=300 \mathrm{~m}^{2} / \mathrm{g}\right)$ is conditioned by a small size (4-40 $\mathrm{nm})$ of its primary particles. It determines high adsorptive capability of UFS while binding many substances, including biomolecules. Silane groups $(\equiv \mathrm{Si}-\mathrm{OH})$ are adsorption centres on the surface of UFS. Hydroxylic surface determines the considerable hydrophilic properties of UFS surface and capability of sorbing polar molecules.

UFS is widely used as an additional substance in the production of many medicinal preparations, as its biological safety has been well established [3]. The studies of the Chuiko Institute of Surface Chemistry,

(c) Institute of Molecular Biology and Genetics NAS of Ukraine, 2010
NAS of Ukraine, have extended the ideas concerning the properties of this silica. It was proven that the addition of UFS in rather low concentrations to the suspension of cells (yeast, microorganisms, gametes, erythrocytes) stimulates their viability [2, 4]. Immobilization of some biomolecules (proteins, carbohydrates, vitamins, etc.) on UFS surface allowed creating BNC, increasing this effect [4].

These results served as a basis for the elaboration of BNC, which allow optimizing cryomedia in the technology of long-term storing a gene pool of some agricultural animals. Different carbohydrates (mono-, oligo- and aminosugars) are used in such BNC. Their introduction into the medium with bovine gametes at the stage of deconservation results in considerable prolongatio of the cells survival [5]. In these studies the method of non-covalent immobilization was used for saccharose, lactose, raffinose as well as for aminosugars N-acetyl-D-glucosamine (GlcNAc) and galactosamine. However, this method appeared 
inefficient for fastening monosugars and $\mathrm{N}$-acetylneuraminic acid (NANA) on the UFS surface [6]. Nevertheless, pretreatment of UFS surface with bovine serum albumin (BSA) allowed fastening these carbohydrates on UFS surface and obtaining BNC on their basis [7].

GlcNAc, tied up on the UFS surface, may become a promising modifier in creating BNC with high level of affinity to oligosaccharide structures of cell surface receptors. For this purpose the parameters of GlcNAc adsorption should be studied as well as a possibility to improve it through the preliminary surface modification with protein. Therefore, the aim of this work was to compare an ability of GlcNAc and NANA to adsorb on the surface of composite adsorbent UFS/BSA, to study some physical and chemical properties of BNC obtained, and to determine their bioactivity in cryomedium in relation to bovine gametes.

Materials and Methods. UFS with hydroxylic surface (A-300) with $S_{s p}=285 \mathrm{~m}^{2} / \mathrm{g}$ (Ukraine), BSA (Fluka, Switzerland), N-AHK and GlcNAc (Sigma, USA) were used in the work.

Adsorption of GlcNAc and NANA on UFS/BSA from the water phase was studied as described in [8]. Initial UFS was an adsorbent for GlcNAc. The adsorbate:adsorbent ratio was 1:10; initial concentrations: BSA - 1-14 mg/ml; GlcNAc - 0.2-1.6 mg/ml, NANA - $16-60 \mu \mathrm{g} / \mathrm{ml}$. The protein was adsorbed at $\mathrm{pH} 4.8$. Adsorption time for BSA and GlcNAc was $2 \mathrm{~h}$, and for NANA $-1 \mathrm{~h}$. The precipitate was isolated by centrifugation for $10 \mathrm{~min}$ at $4000 \mathrm{rpm}$, dried $\left(t=37^{\circ} \mathrm{C}\right)$ and mechanically grained for further investigation. The substance concentration in supernatant was measured by the following methods: for protein - [9]; for GlcNAc - [10], for NANA - [11] with subsequent calculation of adsorption value according to the formula [2]: $A=\left(C_{\text {initial }}-C_{\text {equil }}\right) V / m$, where $C_{\text {initial }}$ and $C_{\text {equil }}-$ initial and equilibrium concentrations in the solution, respectively, $\mathrm{mg} / \mathrm{ml} ; \quad V$ - solution volume, $\mathrm{ml} ; m$-adsorbent mass, g. The measurements were performed on Lambda-35 spectrophotometer (Perkin-Elmer, USA) and photoelectrocolorimeter KFK-2. The efficiency of adsorptive interactions of biomolecules and adsorbent was estimated by adsorption isothermal curves. Calculations of ultimate adsorption $\mathrm{A}_{\infty}$ values were conducted as described in [8].
BNC were studied by IR-spectroscopy in the wavelength range of $4000-400 \mathrm{~cm}^{-1}$ on Thermo Nicolet Nexus FTIR spectrophotometer using the attachment for diffused reflection SMART Collector. Their samples were mixed with preliminary dried $\mathrm{KBr}$ (Riedel-de Haen, France, AR) in the ratios 1:19 for protein and 1:4 for carbohydrate. The omnic software was used for the processing of spectra.

An efficiency of protein interaction with UFS surface was estimated by intensity of band adsorption at the wavelength of $3750 \mathrm{~cm}^{-1}$, distinctive for silane groups, prior to and after BSA adsorption [12].

The mechanism of protein interaction with GlcNAc was studied using ${ }^{1} \mathrm{H}$ NMR spectroscopy on the samples of human serum albumin (HSA) (Kyiv Blood Transfusion Centre). ${ }^{1} \mathrm{H}$ NMR spectra were measured with the high-resolution NMR-spectrometer Varian Mercury 400 , the working frequency of $400 \mathrm{MHz}$ and at $90^{\circ} \mathrm{C}$-probing impulse for $2 \mu \mathrm{s}$. To prevent the overcooling of bound water, ${ }^{1} \mathrm{H}$ NMR spectra were recorded at heating the samples, preliminary cooled to $200 \mathrm{~K}$.

The temperature of samples was regulated using thermal attachment Bruker VT-1000 with $\pm 1 \mathrm{~K}$ precision, integral intensities of signals were determined with $\pm 10 \%$ precision. The characteristics of bound water were determined according to [12-14]. The calculations by cryoporometry method were performed by the procedure, described in $[12,14]$, using Gibbs-Thomson ratio for decrease of water freezing temperature $(\Delta T)$ in cylindrical pores of radius $\mathrm{R}(\Delta T=k / R)$.

Laser-doppler spectroscopy with Spectrolas Instrumentas Model LDS MQE device (Ukraine) was used for determination of BNC biological activity according to the parameters of movement of reproductive cells after deconservation of granules of bovine sperm, cryopreserved in the lactose-glycerol-yolk (LGY) medium [15]. BNC suspended in $2.9 \%$ solution of sodium citrate was added to deconservated sperm. The range of studied concentrations was $0.002-0.6 \%$. The ratio of volumes of sperm and BNC suspensions was 1:3. The measurements were conducted after sperm incubation with BNC at $t=37^{\circ} \mathrm{C}$ for $1 \mathrm{~h}$. The cells were illuminated by laser $\mathrm{He}-\mathrm{Ne}$ at $632.8 \mathrm{~nm}$ in 1-mm cuvettes for $3 \mathrm{~min}$. The action of BNC on cells was estimated by the number of moving cells $(\%)$, frequency of their rotation 

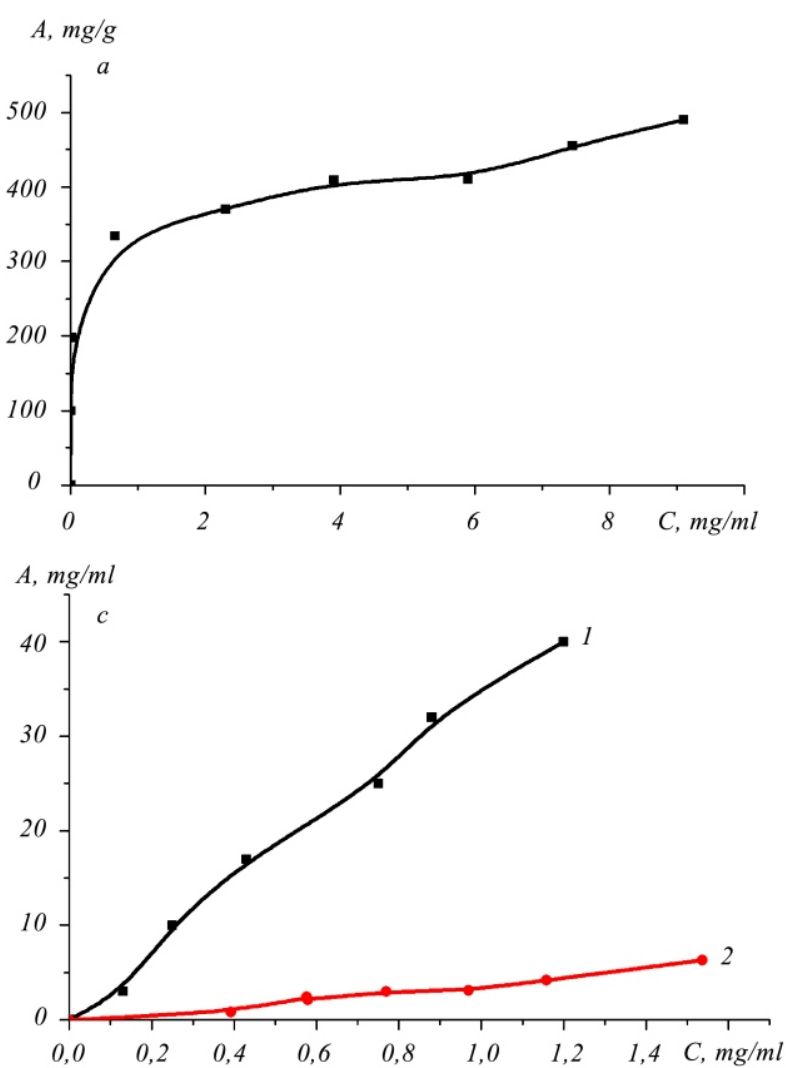

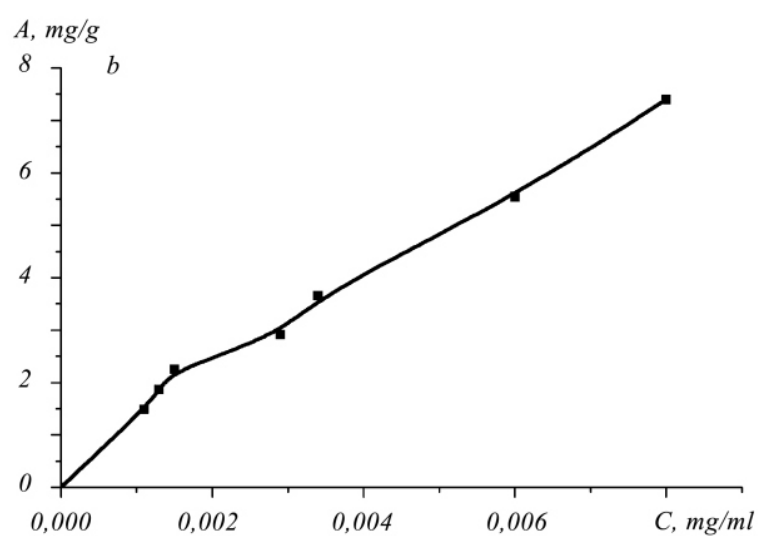

Fig.1 Isothermal curves of adsorption: $a$ - UFS/BSA; $b$ - UFS/BSA/NANA; $c-1$ - UFS/GlcNAc; 2 - UFS/BSA/GlcNAc.
$(\mathrm{Hz})$, speed $(\mu \mathrm{m} / \mathrm{s})$ and motional energy (conventional units). The parameter "motional energy" $(N)$ is energy consumption for movement of cells in viscous medium, calculated by the following formula: $N=\gamma \cdot V^{2}$, where $V$ - speed of cell movement; $\gamma$ - coefficient, related to the form and sizes of sperm cells, and the medium features [15]. The results were obtained with the consideration of decrease in motorial activity of cells in time compared to the control sample without BNS taken as $100 \%$. Bioactivity was estimated by the ratio of cumulative indices in the sample to the control for the whole period of measurements.

Results and Discussion. According to [2] adsorption of BSA on UFS is maximal at its isoelectric point - at $\mathrm{pH}$ 4.8. The isothermal curve looks like Langmuir's curve (Fig.1, a). According to Giles classification of isothermal curves [16], this curve belongs to type L2. Maximal adsorption (A) is 410 $\mathrm{mg} / \mathrm{g}$ which testifies to strong interaction of BSA and UFS. Maximal desorption of BSA from the surface of UFS does not exceed $11.3 \%$.

Preliminary immobilization of BSA on the surface of UFS promotes adsorption of NANA, the isothermal curve of which is presented in Fig.1, $b$. Desorption of NANA from the surface of composite BNC/BSA does not exceed $0.015 \%$.

A comparison of isothermal curves of adsorption, presented in Fig.1, $c$, demonstrates that GlcNAc is sorbed on UFS/BSA several times worse than on UFS. Relatively high adsorption of GlcNAc on UFS may be related to the formation of salt-like adducts with a transferred proton.

Decrease or complete absence of absorption band of free SiOH-groups $\left(v=3750 \mathrm{~cm}^{-1}\right.$, Fig. 2$)$ is observed in IR-spectra of carbohydrates, interacting with UFS or UFS/BSA composite, which proves their binding to the functional groups of adsorbed molecules [2]. The shifts in absorption bands of Amid I-valence vibrations $\mathrm{C}=\mathrm{O}$ and $\mathrm{C}-\mathrm{N}$ (from 1650 to $1657 \mathrm{~cm}^{-1}$ ) and Amid II-valence $\mathrm{C}-\mathrm{N}$ and deformational vibrations $\mathrm{NH}$ (from 1550 to $1657 \mathrm{~cm}^{-1}$ ), evident in IR-spectroscopy of proteins, were observed in BNC of UFS/BSA [17]. It testifies to the formation of $\mathrm{H}$-bond between $\mathrm{NH}$-groups of BSA molecule and hydroxyls of UFS [18].

A considerable decrease in the intensity of absorption band at $3750 \mathrm{~cm}^{-1}$ in case of the formation of 

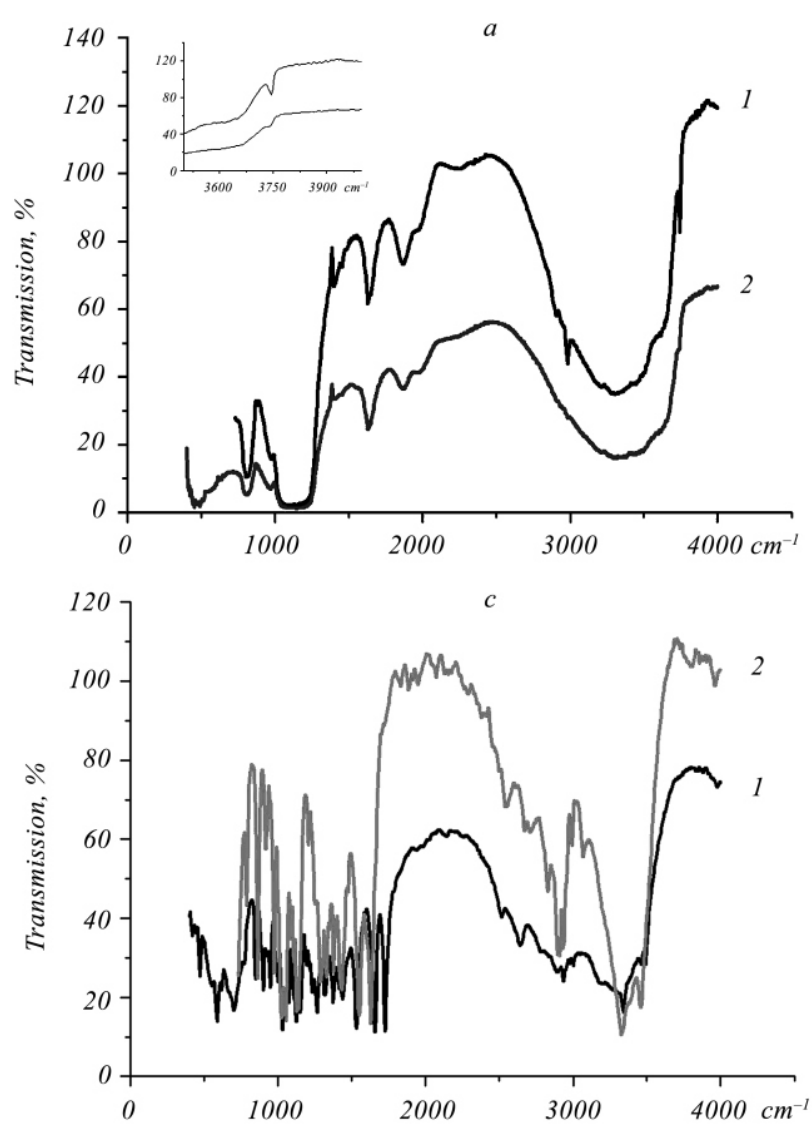

UFS/GlcNAc (Fig. 2, a) is conditioned by the participation of SiOH-groups in hydrogen bonds of GlcNAc with UFS. At the same time there is a wide absorption band in the range of $2700-3600 \mathrm{~cm}^{-1}$, caused by simultaneous appearance of $\mathrm{NH}$ bonds in aminogroup (3350 $\left.\mathrm{cm}^{-1}\right)$ and valence vibrations of $\mathrm{CH}-(2960,3020,3300$ $\left.\mathrm{cm}^{-1}\right)$ and $\mathrm{OH}$-groups $\left(3550 \mathrm{~cm}^{-1}\right)$ [18].

In IR-spectra of UFS/BSA/GlcNAc composite (Fig.2, $b$, spectrum 3) there are an evident shoulder at $1630 \mathrm{~cm}^{-1}$, corresponding to physically adsorbed water, and an absorption band in the range of 1730 $\mathrm{cm}^{-1}$, which belongs to vibrations $\mathrm{C}=\mathrm{O}$-group of aminosugar (1850-1550 $\left.\mathrm{cm}^{-1}\right)$ [19]. IR-spectra also show peaks at 1545 and $1650 \mathrm{~cm}^{-1}$, corresponding to deformational vibrations of $\mathrm{NH}_{2}$-group, and an absorption band at $1520 \mathrm{~cm}^{-1}$ of deformational vibrations of NH-group.

In general, IR-spectrum of UFS/BSA/NANA composite is similar to that of GlcNAc. It was observed the vanishing or decrease of absorption bands in the range of $3500-3100 \mathrm{~cm}^{-1}$, specific for $\mathrm{NH}-$ bond in aminogroup of carbohydrates, a band of $1730 \mathrm{~cm}^{-1}$, as

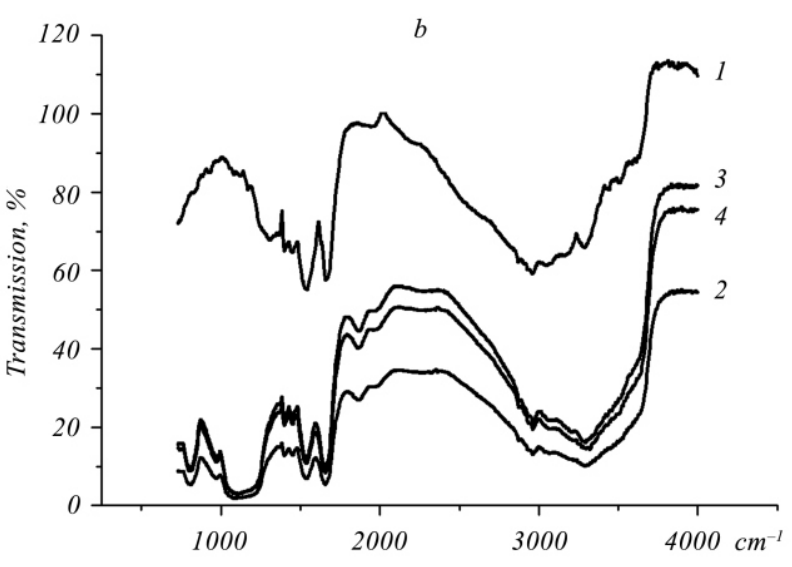

Fig.2 IR-spectra of bionanocomposites on the basis of: $a$ UFS (1) and UFS/GlcNAc (2); $b$ - BSA (1), UFS/BSA (2), UFS/BSA/GlcNAc (3), UFS/BSA/NANA (4); $c$ - NANA (1) and GlcNAc (2)

well as a number of bands in the range of 1241-1015 $\mathrm{cm}^{-1}$, corresponding to frequencies of deformational vibrations of groups $\mathrm{CH}_{3}, \mathrm{CH}_{2}$, and $\mathrm{CH}$ [20]. Therefore, immobilization of GlcNAc and NANA on the surface of UFS/BSA composite occurs with the participation of hydroxylic, carbonyl and aminogroups of both protein and the carbohydrates studied.

The binding of GlcNAc to albumin globules in solutions was studied in order to reveal the reasons of weak desorption of GlcNAc from the surface of UFS/BSA composite. Fig. 3 demonstrates ${ }^{1} \mathrm{H}$ NMR spectra of non-freezing water in 5\% solutions of albumin - an initial one and solutions, containing GlcNAc additions. The signal is irregular; when resolved into components in the assumption of Gaussian form of absorption lines, it may be presented by two signals with the chemical shifts $\delta_{\mathrm{H}}=5$ and 5.7 parts per million (ppm). The intensities of these signals are in $3: 1$ ratio.

The data in Fig.4 demonstrate the temperature dependences of non-freezing water concentration, calculated by temperature changes in the intensity of 

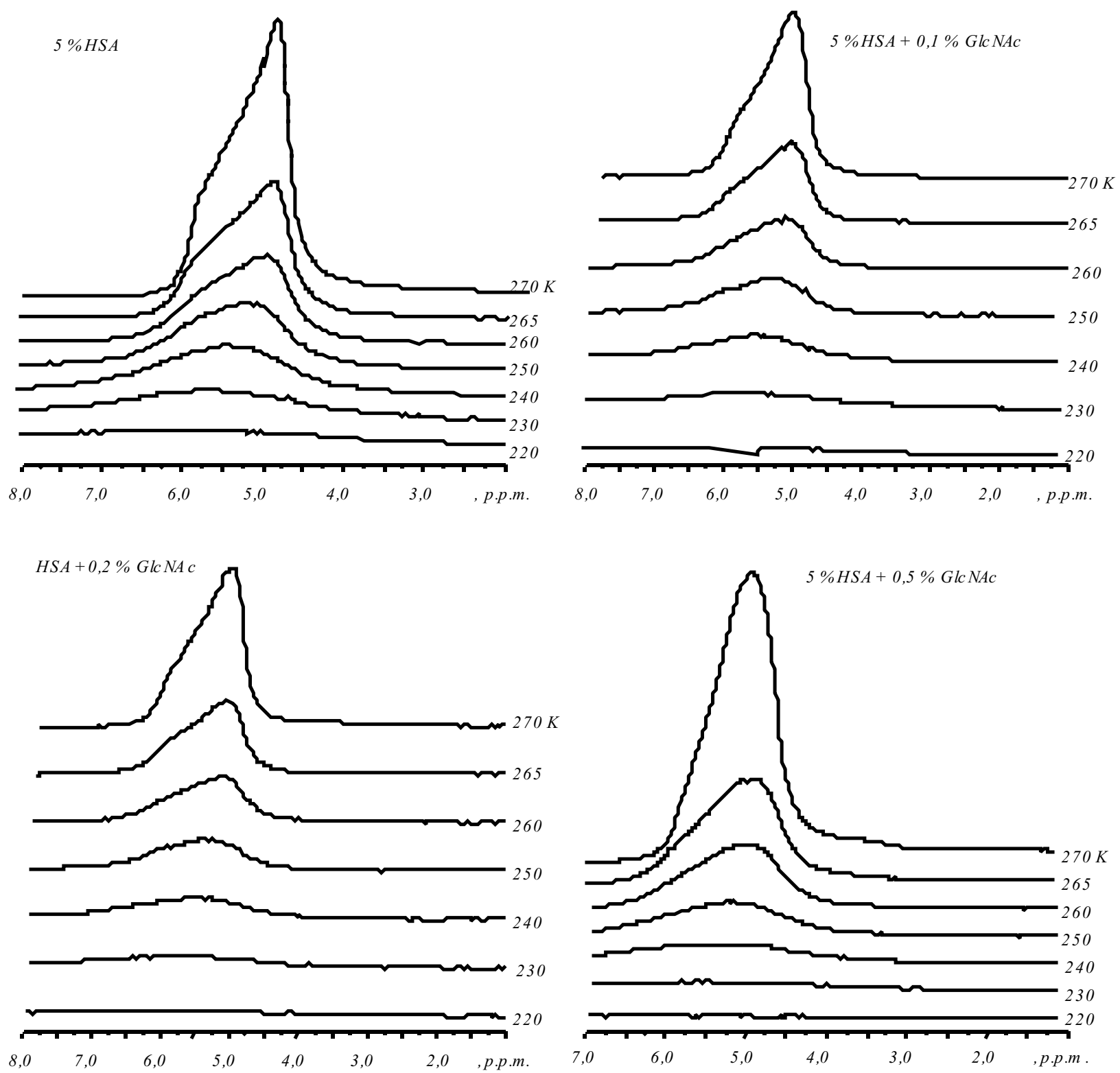

Fig. 3 Temperature dependences of ${ }^{1} \mathrm{H}$ NMR spectra of water at deconservation of $5 \%$ water solutions of human serum albumin (HSA), containing $0(a) ; 0.1(b) ; 0.2(c)$ and $0.5 \%(d)$ of GlcNAc, respectively

water signal, comparing with the intensity of water signal prior to freezing (which is $19 \mathrm{~g} / \mathrm{g}$ for $5 \%$-solution of HSA); dependences of changes in free Gibbs energy on the concentration of non-freezing water; temperature dependences of changes in concentration of non-freezing water, conditioned by the presence of GlcNAc; distribution of non-freezing water along the radii of nanodrops of strongly associated water; and changes in $\Delta C_{u w}$ depending on the value of $\Delta G$. The values $\Delta_{1}$ were calculated determining the difference in $C_{u w}$ at fixed temperature of measurements. The radii of nanodrops of non-freezing water were calculated by Gibbs-Thomson equation $(R=\Delta T / k$, where $k=50$ degrees $\times \mathrm{nm}$ [12]) for the portions of water, frozen at changing temperature in the range from $T_{1}$ to $T_{2}$.

As seen from the data in Fig.4, $c$, dependences $\Delta_{1}(T)$ are complex. At $T=270 \mathrm{~K} \quad \Delta>0$, i.e. the presence of GlcNAc increases the concentration of non-freezing water in the system. The increase in $\mathrm{C}_{\mathrm{uw}}$ is $50-100 \mathrm{mg} / \mathrm{g}$ (up to $15 \%$ from $\mathrm{C}_{\mathrm{uw}}{ }^{\max }$ ) at $\mathrm{C}_{\mathrm{GlcNAc}}=$ $0.05-0.5 \%$. One of the reasons of increase in $\mathrm{C}_{\mathrm{uw}}$ may 

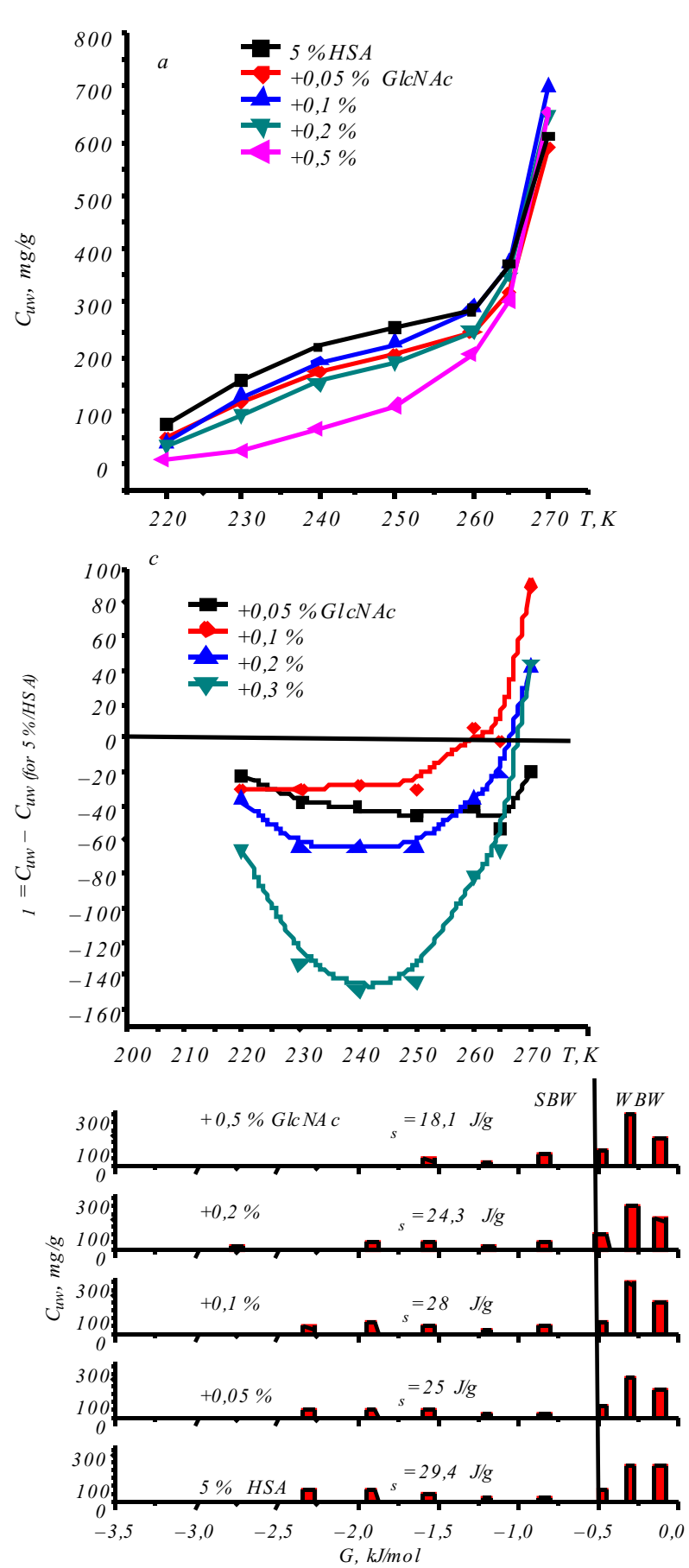

be decrease in freezing temperature of the solution, conditioned by the decrease in the density of saturated vapour (Raul's law). However, taking into consideration the fact that $\mathrm{C}_{\mathrm{GlNAc}}$ does not exceed 1 $[\times] 10^{-4} \mathrm{mg} / \mathrm{l}$, freezing temperature cannot decrease more than by 0.1 degree, i.e. this is not the main reason. At $T<270 \mathrm{~K}$ the value $\Delta_{1}<0$, with a wide minimum at $T=240 \mathrm{~K}$ in the dependences $\Delta_{1}(T)$. Maximal decrease
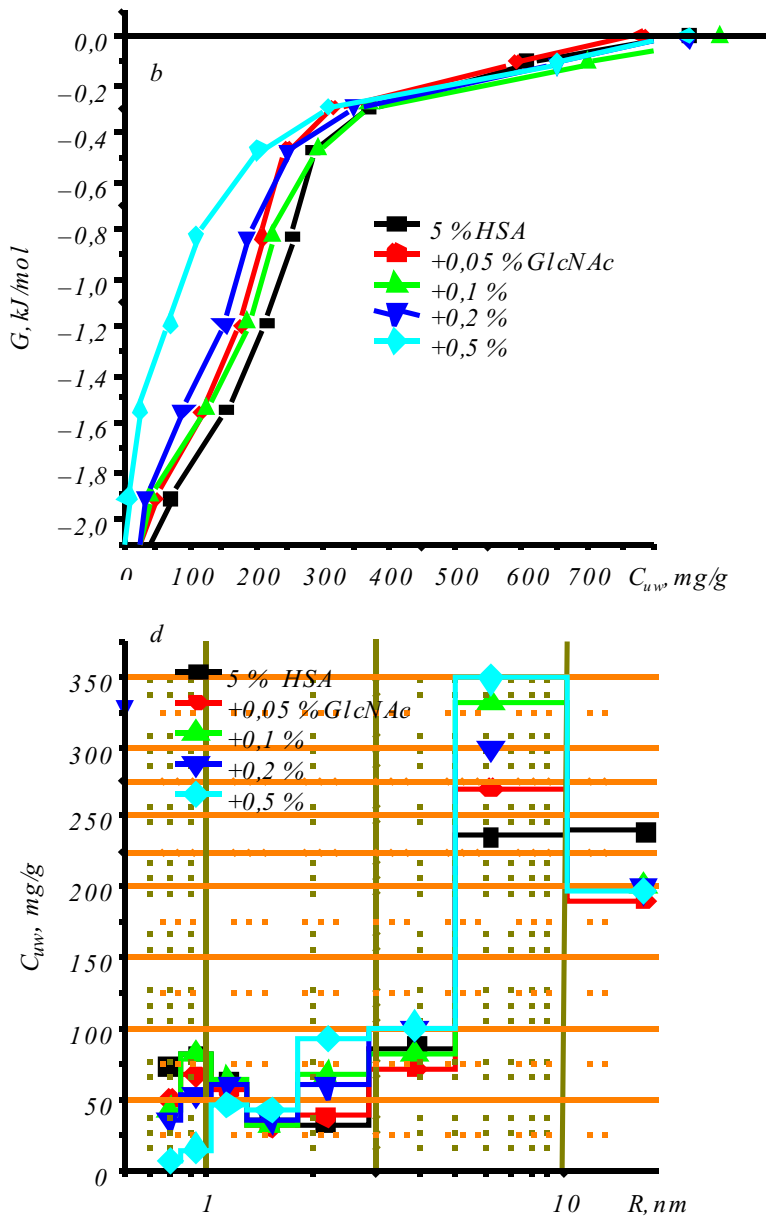

Fig.4 Temperature dependences of concentration of non-freezing water $\left(C_{u w}\right)(a)$, dependences of free Gibbs energy $(\Delta G)$ on $C_{u w}(b)$, changes in $C_{u w}$, caused by the presence of GlcNAc (c), distribution of non-freezing water along the radii of cavities, filled with water, inside a biopolymer matrix $(d)$ and $\Delta C_{u w}$ according to changes in $\Delta G(e)$.

in the concentration of non-freezing water was observed for the sample, containing $0.05 \%$ GlcNAc.

The regularities obtained may be explained by efficient interaction of GlcNAc and albumin molecules. As protein molecules are highly hydrated, the molecules of organic admixture (GlcNAc in our case) are capable of replacing a part of hydrate water. It is reasonable to expect such decrease in hydration 
degree that corresponds to the replacement of the volume of hydrate water, equal to the volume of molecules of organic admixture [12]. The data in Fig.4, $c$ show that maximal decrease in $C_{u w}$ volume reaches $160 \mathrm{mg} / \mathrm{g}$ which is an order higher than this volume. Therefore, the main reason of the observed peculiarities of behaviour of dependences $\Delta_{1}(T)$ should be considered altering of the interaction parameters in microgel structures of protein which may become either stronger (which results in decrease in $C_{u w}$ value) or weaker in accordance to $C_{\mathrm{GlcNAc}}$.

The use of Gibbs-Thomson equation allows determining a size distribution of water clusters or cavities (compartments), filled with water in frozen aqueous solutions of albumin, and the influence of organic admixture molecules (GlcNAc) on them (Fig.4, d). Several compartments, the number of which is determined by the number of points on temperature dependence $C_{u w}(T)$ ), with the radii in the range of $0.7-11 \mathrm{~nm}$ can be identified. According to the data in Fig. $4, b$, water in clusters with the radii of 6 and $11 \mathrm{~nm}$ may be related to weakly bound water. The transition area is conditioned by clusters with the radii of 2 and 4 $\mathrm{nm}$; strongly bound water (SBW) - by the clusters with $R<2 \mathrm{~nm}$.

As seen from the data in Fig.4, $d$, GlcNAc admixtures have different influence on the amount of water, located in clusters of different size. The volume of SBW, localized in small cavities, decreases while the volume of water in cavities with the radii of 2 and 6 $\mathrm{nm}$ increases considerably. Therefore, there are two opposite tendencies in the change in volumes of water structures, which determine a relatively weak dependence of the interphase energy in a wide range of concentrations of GlcNAc admixtures, which distinguishes it from plain sugars (glucose and fructose) [12]. While interacting with the fragments of protein molecules, GlcNAc is likely to block the centres of their intermolecular binding. Taking into consideration that GlcNAc molecules contain electron-donating atoms of nitrogen and oxygen, it is possible to assume its interaction with the protein in acid centres mainly. The data in Fig. $4, d$ demonstrate that at $T=270 \mathrm{k}$ water in cavities with the radii of $6 \mathrm{~nm}$ freezes. It is most likely that the cavities of this size are located in spaces between closely located albumin molecules (the size of protein globule does not exceed $7 \mathrm{~nm}$ ). Therefore, the breaking of protein-protein bonds results in the formation of clusters of this very size in albumin microgel. In BNC of UFS/BSA, the biopolymer molecules cover a considerable area of silica surface. Thus, it is possible to assume that protein fraction on the surface of silica acts in a way, similar to the behaviour of microgel structures in the solution.

The study of parameters of mobility of deconserved bovine sperm gametes in the presence of $\mathrm{BNC}$ demonstrates a biological activity of the gametes that becomes evident through the increase in studied indices for experimental samples compared to the control. There is also an evident dependence of this result on the $\mathrm{BNC}$ concentration in the medium with cells. In this respect an obvious parameter is motional energy which is proportional to the force of the moving cell (which depends on its friction in viscous medium) and the speed of movement [15]. The increase in mobility of this type of cells testifies to the increase in viability [2].

Fig. 5 demonstrates a histogram which allows comparing bioactivity of obtained BNC by the ratio of cumulative energy of gametes to that of the control cells. An increase in the motional energy of gametes compared to the control was observed in the range of studied concentrations (except for $C_{U F S / B S A N A N A}=$ $0.002 \%)$. The highest activity is notable for UFS/GlcNAc composite and the lowest - for UFS/BSA/NANA. Optimal concentrations of nanocomposite in cryomedium were as follows: $0.15 \%$ for UFS/GlcNAc and UFS/BSA/NANA, $0.6 \%$ for UFS/BSA/GlcNAc.

It is noteworthy that optimal concentrations of $\mathrm{BNC}$, obtained by measuring the motional energy of gametes, are also proven by other parameters, namely, speed and frequency of cell rotation. Maximal number of movable cells was registered at relatively low concentrations of BNC: $C_{o p}=0.01 \%$ for UFS/BSA/NANA and UFS/GlcNAc, $0.15 \%$ for UFS/BSA/GlcNAc. This may be explained by different physiological state of the cells in gamete suspension [21], which means that their sensitivity to the same BNC concentration will be different.

The results obtained prove that all created $\mathrm{BNC}$ are capable of increasing the viability of gametes. 


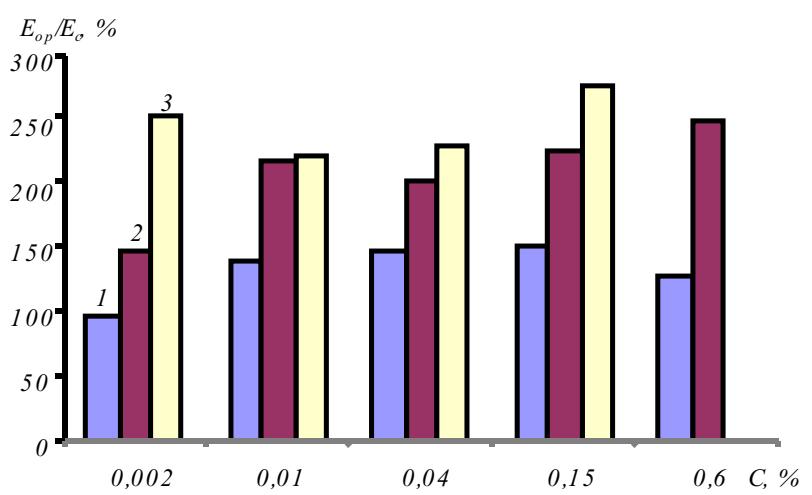

Fig.5. Dependence of motional energy of deconservated bovine gametes on $\mathrm{BNC}$ concentration: $E_{\mathrm{op}}$ - cumulative energy for experimental sample; $E_{\mathrm{c}}$ - the same for the control (1 UFS/BSA/NANA; 2 - UFS/BSA/GlcNAc; 3 - UFS/GlcNAc)

However, preliminary immobilization of protein on UFS surface leads to some decrease in the mobility of gametes (it may be conditioned by complete screening of silane groups by protein molecules) as well as in too firm binding of GlcNAc and NANA to BSA, fixed on the surface of BSA adsorbent (which is proven by the results of desorption, NMR- and IR-spectroscopy). There are grounds for the assumption that the action of $\mathrm{BNC}$ on cells depends considerably on the character of binding of immobilized biomolecules to the surface of adsorbent. Probably, predominant desorption of aminocarbohydrates from the BNC surface close to the receptor system promotes their integration into the cell metabolism. However, other mechanisms are also possible, for instance, the alteration of the cryomedium properties under the influence of BNC. It is also possible that BNC with immobilized carbohydrates may interact selectively with specific sites of the cell surface and therefore influence the activity of enzymes, built into the membrane.

Conclusions. It was shown that modification of the UFS surface with BSA protein allows immobilizing both GlcNAc and NANA on it. Triple BNC, obtained on this basis, have relatively high biological activity. The molecules of immobilized aminocarbohydrates provide the activity of BNC even when the UFS surface is completely screened by the protein molecules. The parameters of adsorption/desorption of studied carbohydrates on UFS and the data of IR-spectroscopy allow the assumption that their immobilization on the surface of UFS/BSA composite occurs due to the formation of hydrogen-bound complexes with the participation of amino- and amid groups of both protein and carbohydrates. It was demonstrated that the interaction of aminosugar and protein was accompanied by considerable dehydratation of protein structures, caused mainly by the decrease in the efficiency of protein-protein bonds. It was also determined that BNC on the basis of UFS, BSA, GlcNAc and NANA in the range of specific concentrations can be applied for optimization of LGY-cryomedium to stimulate the viability of deconservated bovine gametes.

The granules of cryopreserved bovine sperm were kindly provided by the Institute of Animal Breeding and Genetics, UAAS.

The work was supported by the complex programme of fundamental research of the National Academy of Sciences of Ukraine "Nanostructural systems, nanomaterials, nanotechnologies".

\section{Н. П. Галаган, Н. Ю. Клименко, И. Л. Орел, Е. А. Новикова,} B. В. Туров

Биофункциональные наноматериалы на основе высокодисперсного кремнезема, белка и аминоуглеводов

Резюме

Цель. Исследование адсорбиионных взаимодействий $N$-аиетил-D-глюкозамина (GlcNAc) и $N$-ацетилнейраминовой кислоmы (N-AHK) с высокодисперсным кремнеземом (ВДК), модифицированным белком бычьим сывороточным альбумином (БСА). Методы. Адсорбция, ИК-, 'Н ЯМР- и лазерно-допплеровская спектроскопия. Результаты. Разработаны условия получения бионанокомпозитов (БНК) ВДК/GlcNAc; ВДК/БCA/GlcNAc и ВДК/БСА/N-AНК. Выводы. Двигательная способность деконсервированных гамет быка снижается в присутствии БНК после адсорбиионного закрепления на его поверхности белка. На основе данных ${ }^{1} H$ ЯМР-спектроскопии установлено, что взаимодей- ствие GlcNAc с белком сопровождается сильной дегидратаиией его молекул.

Ключевые слова: высокодисперсный кремнезем, альбумин, углеводы, бионанокомпозиты, сперма быка.

Н. П. Галаган, Н. Ю. Клименко, І. Л. Орел, О. А. Новікова, B. В. Туров

Біофункціональні наноматеріали на основі високодисперсного кремнезему, білка та аміновуглеводів

Резюме

Мета. Дослідження адсорбиійних взаємодій $N$-ацетил-D-глюкозаміну (GlcNAc) та N-ацетилнейрамінової кислоти (N-AHK) з високодисперсним кремнеземом (ВДК), модифікованим білком бичачим сироватковим альбуміном (БСА). Методи. Ад- 
сорбиія, IЧ-, ${ }^{1}$ Н ЯМР- та лазерно-допплерівська спектроскопія. Результати. Розроблено умови отримання біонанокомпозитів (БНК): ВДК/GlcNAc; ВДК/БCA/GlcNAc та ВДК/БCA/NАНК. Висновки. Здатність до руху деконсервованих гамет бика знижується за присутності БНК після адсорбиійного закріплення на його поверхні білка. На основі даних ${ }^{1} \mathrm{H}$ ЯМРспектроскопії встановлено, що взаємодія GlcNAc з білком супроводжується сильною дегідратачією його молекул.

Ключові слова: високодисперсний кремнезем, альбумін, вуглеводи, біонанокомпозити, сперма бика.

\section{REFERENCES}

1. Chemistry of surface of silica / Ed. A. A. Chuiko.-K.: Ukr. INTEI, 2001.-736 p.

2. Medical chemistry and clinical application of dioxide of silicon / Ed. A. A. Chuiko.-Kyiv: Naukova dumka, 2003.-415 p.

3. Aljushin M. T., Astrahanova M. M. Aerosil and its application in a pharmaceutical practice // Pharmacy.-1958.-17, N 6.P. 73-77.

4. Nedava V. E., Smirnova O. I., Zuravel M. P., Galagan N. P., Bogomaz V. I., Chuiko A. A., Sinelnik A. P., Mihnjuk V. P. About use of ultrafine silica in environments for freezing sperm of rams // Agricult. Biol. Ser. Biol. Anim.-1992.-N 4.P. 20-25.

5. Vlasenko V. V., Galagan N. P., Kulik T. V., Pokrovskiy V. A. Studies on adsorption or carbohydrates on ultrafine silica surface by means of mass spectrometry and laser Doppler spectrometry // VII Polish-Ukrainian Symp. on theoretical and experimental studies of interfacial phenomena and their thechnological applications.-Lublin, 2003.-P. 312-314.

6. Kulik T. V., Paljanitsja B. B., Galagan N. P. Molecular selforganizing in systems nanodimensional particles-carbohydrates // Nanosystems, Nanomaterials, Nanotechnologies.2004.-1, N 2.-P. 681-690.

7. Galagan N. P., Nastasienko N. S., Grytsenko I. V., Chmilev $M$. V., Vlasenko $V$. $V$. Research nanocomposites on the basis of ultrafine silica modified poliols and the bovine serum albumin // Nanosystems, Nanomaterials, Nanotechnologies.2004.-2, N 2.-P. 597-608.

8. Mitrophanov P. P. Practical work on physical and colloid chemistry.-M.: Medgiz, 1950.-183 p.
9. Kochetov G. A. Practical guidance on enzymology.-M.: Higher school, 1980.-P. 222-226.

10. Varbanets L. D., Zdorovenko G. M., Knirel Yu. A. Methods of endotoxin investigations.-Kyiv: Naukova dumka, 2006.$239 \mathrm{p}$.

11. Methods of biochemical researches (lipid and a power exchange) / Ed. M. I. Prohorovoj.-L.: Publ. Leningr. Univ., 1982.-272 p.

12. Gun'ko V. M., Turov V. V., Gorbik P. P. Water at the interface.-Kyiv: Naukova dumka, 2009.-694 p.

13. Turov $V$. $V$., Leboda R. Application of ${ }^{1} \mathrm{H}$ NMR spectroscopy method for determination of characteristics of thin layers of water adsorbed on the surface of dispersed and porous adsorbents // Adv. Coll. Interf. Sci.-1999.-79, N 2-3.-P. 173-211.

14. Gun 'ko V. M., Turov V. V., Bogatyrev V. M., Zarko V. I., Leboda R., Goncharuk E. V., Novza A. A., Turov A. V., Chuiko $A$. A. Unusual properties of water at hydrophilic/hydrophobic interfaces // Adv. Coll. Interf. Sci.-2005.-118, N 1-3.P. $125-172$.

15. Galagan N. P., Vlasenko V. V., Nastasienko N. S., Chuiko O. $O$. Investigation of effect ultrafine silica and its composites with polyols on vital capacity of reproductive cells by the means of photon-correlation spectroscopy // Biophys. Bull. Khark. Univ.-2005.-1 (15), N 665.-P. 94-98.

16. Adsorption from solutions at the solid/liquid interface / Eds G. D. Parfitt, C. H. Rochester.-M.: Mir, 1986.-488 p.

17. Chirgadze $Y u$. N. Infrared spectra and structure of polypeptides and proteins.-M.: Nauka, 1965.-134 p.

18. Tarasevich Yu. I., Monahova L. I. Interaction of globular albumins with silica surface // Colloid. J.-2002.-64, N 4.P. 535-540.

19. Kochetkov N. K., Bochkov A. F., Dmitriev B. A., Usov A. I., Chizhov O. S., Shibaev V. N. Chemistry of carbohydrates.-M.: Chemistry, 1967.-672 p.

20. Dudkin $M$. S. Introduction into chemistry of carbohydrates.-Kyiv: Higher school, 1976.-176 p.

21. Nemirovsky L. E., Solov'ev I. G., Lyamov S. V Cell activation is a high-speed process // Reps of the RAS.-1992.-326, N 1.P. 184-188.

UDC 546.284-31 + 547.962.3 + 547.454 + 576.322 Received 03.11.09 